\title{
Effects of Concentration and Reaction Time of Trypsin, Pepsin, and Chymotrypsin on the Hydrolysis Efficiency of Porcine Placenta
}

\author{
Kyung-Hun Jung ${ }^{1}$, Ye-Chul Choi ${ }^{1}$, Ji-Yeon Chun ${ }^{1}$, Sang-Gi Min ${ }^{1}$, and Geun-Pyo Hong* \\ Department of Food Bioengineering, Jeju National University, Jeju 690-756, Korea \\ ${ }^{1}$ Department of Bio-Industrial Technologies, Konkuk University, Seoul 143-701, Korea
}

\begin{abstract}
This study investigated the effects of three proteases (trypsin, pepsin and chymotrypsin) on the hydrolysis efficiency of porcine placenta and the molecular weight $(\mathrm{Mw})$ distributions of the placental hydrolysates. Because placenta was made up of insoluble collagen, the placenta was gelatinized by applying thermal treatment at $90^{\circ} \mathrm{C}$ for $1 \mathrm{~h}$ and used as the sample. The placental hydrolyzing activities of the enzymes at varying concentrations and incubation times were determined by sodium dodecyl sulfate polyacrylamide gel electrophoresis (SDS-PAGE) and gel permeation chromatography (GPC). Based on the SDS-PAGE, the best placental hydrolysis efficiency was observed in trypsin treatments where all peptide bands disappeared after $1 \mathrm{~h}$ of incubation as compared to $6 \mathrm{~h}$ of chymotrypsin. Pepsin hardly hydrolyzed the placenta as compared to the other two enzymes. The Mw distribution revealed that the trypsin produced placental peptides with Mw of 106 and 500 Da. Peptides produced by chymotrypsin exhibited broad ranges of Mw distribution (1-20 kDa), while the pepsin treatment showed Mw greater than $7 \mathrm{kDa}$. For comparisons of pre-treatments, the subcritical water processing $\left(37.5 \mathrm{MPa}\right.$ and $\left.200^{\circ} \mathrm{C}\right)$ of raw placenta improved the efficiency of tryptic digestions to a greater level than that of a preheating treatment $\left(90^{\circ} \mathrm{C}\right.$ for $1 \mathrm{~h}$ ). Consequently, subcritical water processing followed by enzymatic digestions has the potential of an advanced collagen hydrolysis technique.
\end{abstract}

Key words: porcine placenta, collagen peptide, hydrolysis, protease, efficiency

\section{Introduction}

Collagen is an abundant protein in animal skin and organs. Collagen is composed of a triple-helix of chain structures repeated with glycine-X-Y where $\mathrm{X}$ and $\mathrm{Y}$ are predominantly proline and hydroxyproline (Miller, 1988). Collagen has not attracted interest from a nutritional perspective because of its poor composition of sulfur-containing amino acids. However, collagen-derived hydrolysates are considered as an important functional food as well as the pharmaceutical and cosmetic industries (Zhang et al., 2006).

It is a relatively new concept that low molecular weight (Mw) peptides possess various advantageous nutritional and physiological functions. These functions include physicochemical properties (solubility, emulsifying, water binding, and foaming capacity), antioxidant activity, antihy-

\footnotetext{
*Corresponding author: Geun-Pyo Hong, Department of Food Bioengineering, Jeju National University, Jeju 690-756, Korea. Tel: 82-64-754-3615, Fax: 82-64-755-3601, E-mail: gphong@, jejunu.ac.kr
}

pertensive activity, antimicrobial activity and antianemia activity (He et al., 2013). Besides these functions, moisturizing, softening and skin reproducing functions have enabled collagen hydrolysates to be a focus in bio-industry (Yorgancioglu and Bayramoglu, 2013).

Until now, commercial collagen hydrolysis has been achieved by acid or alkali treatment, although proteases have also been used to obtain low Mw collagen peptides. Acid or alkali hydrolysis is an approved economical process (Denis et al., 2008); however, acid-hydrolyzed collagen must be neutralized and desalted. In addition, acid and alkali hydrolysis require a long processing time (about $24 \mathrm{~h}$ ). Enzymatic processing is an alternative to produce commercial collagen peptides. Various proteases including trypsin, pepsin, chymotrypsin, alcalase, collagenase, and papain are applicable depending on the purpose of the final products (Gómez-Guillén et al., 2011).

Applying subcritical water is a novel technique to degrade organic compounds, including proteins, carbohydrates and lipids; hence, it is commercially used for waste processing (Yang et al., 1997). The critical point of water is $374^{\circ} \mathrm{C}$ at $22 \mathrm{MPa}$ at which water ionizes readily to 
hydrogen and hydroxide ions and the hydrogen ions cause the disruption of peptide bonds (Brunner, 2009; Watchararuji et al., 2008). We found in a previous study that subcritical water processing hydrolyzed animal by-product collagen (Lee et al., 2013). Both conversion of collagen to gelatin and partial hydrolysis of gelatin occur during subcritical water processing, however, the majority of the gelatin hydrolysates have $\mathrm{Mw}>10 \mathrm{kDa}$, which limits subcritical water processing as a collagen hydrolyzing technology.

Collagen peptides of 1-2 $\mathrm{kDa}$ are recommended as functional food or cosmetic ingredients and enzymatic digestion is essential (Chai et al., 2010). Numerous proteases can be used for protein hydrolysis, but the actual activity and efficiency of these enzymes on animal by-product collagen have rarely been compared. Therefore, we compared the effects of three representative enzymes (trypsin, pepsin, and chymotrypsin) on hydrolysis of porcine placenta and $\mathrm{Mw}$ distribution of the placental hydrolysates. In addition, effect of subcritical water processing on the enzymatic digestion and $\mathrm{Mw}$ characteristics of placental peptides was also explored.

\section{Materials and Methods}

\section{Materials}

Frozen porcine placenta was donated by Samwoo Husbandry (Korea). The frozen placenta was thawed in running water for $4 \mathrm{~h}$ and washed to remove residual blood. All visible fat was trimmed, and the placenta was cut into $5 \mathrm{~cm}$ lengths. Crude protein $(5.8 \%)$ and moisture contents $(92.2 \%)$ of the placenta were determined by Kjeldahl $(\% N \times 6.25)$ and a $102^{\circ} \mathrm{C}$ air drying AOAC (1990) method, respectively. The placenta was vacuum-packaged and frozen at $-50^{\circ} \mathrm{C}$ prior to use (within 2 mon). Trypsin (T4549), pepsin (P6887), and chymotrypsin (C4129) were purchased from Sigma-Aldrich Co. (USA), and used without further processing (Table 1). All chemicals were analytical grade.

\section{Pretreatment}

Placenta was thawed at $4^{\circ} \mathrm{C}$ overnight and homogenized using a SMT homogenizer (SMT Co., Ltd., Japan) at $14,000 \mathrm{rpm}$ for $5 \mathrm{~min}$. A preliminary study indicated that raw placenta does not undergo hydrolysis in various concentrations of trypsin (Fig. 1), hence, the placenta was pretreated to convert the collagen to soluble gelatin. The raw collagen suspension was transferred to a $50 \mathrm{~mL}$ test tube and heated in a $90^{\circ} \mathrm{C}$ water bath for $1 \mathrm{~h}$, then cooled
Table 1. Characteristics and activity of selected enzymes

\begin{tabular}{cccc}
\hline \hline Enzyme & $\begin{array}{c}\text { Optimum } \\
\mathrm{pH}\end{array}$ & $\begin{array}{c}\text { Molecular } \\
\text { weight }\end{array}$ & Activity \\
\hline Trypsin & $7-8$ & $24 \mathrm{kDa}$ & $\begin{array}{c}10,000 \mathrm{BAEE} \\
\text { unit/mg }\end{array}$ \\
Pepsin & $2-3$ & $34 \mathrm{kDa}$ & $3,200 \mathrm{unit} / \mathrm{mg}$ \\
Chymotrypsin & $7-8$ & $25 \mathrm{kDa}$ & $40 \mathrm{unit} / \mathrm{mg}$ \\
\hline
\end{tabular}

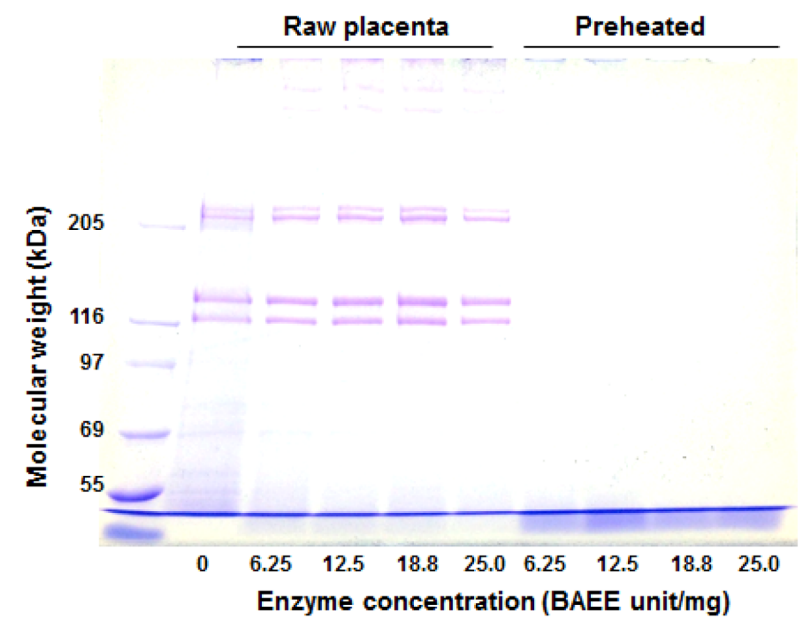

Fig. 1. Sodium dodecyl sulfate-polyacrylamide gel electrophoresis patterns of raw and preheated $\left(90^{\circ} \mathrm{C}\right.$ for $\left.1 \mathrm{~h}\right)$ porcine placenta after a $24 \mathrm{~h}$ incubation with various concentrations of trypsin.

to $30^{\circ} \mathrm{C}$ in water. Subcritical water processing was conducted using a high pressure device as described previously (Lee et al., 2013). Raw placenta was inserted into the pressure vessel and pressurized to $37.5 \mathrm{MPa}$. The temperature was increased to $200^{\circ} \mathrm{C}$ while maintaining pressure. When the inside of the vessel reached the target temperature ( $\sim 90 \mathrm{~min})$, the vessel was cooled to $40^{\circ} \mathrm{C}$ in ice.

\section{Hydrolysis procedure}

Selected enzyme stock was prepared by dissolving an adequate enzyme concentration in water. The enzyme solutions were mixed with pretreated placenta suspensions and incubated for $24 \mathrm{~h}$ at $37^{\circ} \mathrm{C}$. Based on the product information, the trypsin stock was prepared to contain 25 BAEE unit/mg enzyme in the mixture, whereas pepsin and chymotrypsin were prepared to contain 40 units $/ \mathrm{mg}$ in the mixture. Enzyme concentration was controlled by diluting the stock solution with distilled/deionized water. At given times, the mixture was removed from the incubator and heated to $70^{\circ} \mathrm{C}$ for $30 \mathrm{~min}$ to inactivate the enzyme. The sample was kept at ambient temperature for $1 \mathrm{~h}$ and used for analysis. 


\section{Gel electrophoresis}

The pretreated placenta and enzyme mixture was transferred to a test tube and vortexed vigorously. Aliquots of $100 \mu \mathrm{L}$ of sample were diluted with $400 \mu \mathrm{L}$ of $8 \mathrm{M}$ urea (final protein concentration, $4 \mathrm{mg} / \mathrm{mL}$ ). Peptide profiles of samples were determined by sodium dodecyl sulfate-polyacrylamide gel electrophoresis (SDS-PAGE) using 12\% acrylamide gels (EzWay $^{\mathrm{TM}}$ PAG, KOMA Biotech Inc., Korea) based on the method of Laemmli (1970). Samples were mixed with one part sample buffer (KTG020, KOMA Biotech Inc., Korea), consisting of $10 \%$ glycerol, 2\% SDS, $0.003 \%$ bromophenol blue, $5 \% \beta$-mercaptoethanol, and $63 \mathrm{mM}$ Tris ( $\mathrm{pH}$ 6.8). The sample was boiled for 2 min and $20 \mu \mathrm{L}$ of the sample mixture was loaded into gel wells. Peptide separation was performed at a constant voltage of 140 V. Pre-stained marker (K18000, EzWay ${ }^{\mathrm{TM}}$, protein-preblue marker, KOMA Biotech Inc., Korea) was used as Mw standard.

\section{Molecular weight distribution}

The Mw distribution of the placenta hydrolysates was determined by the method of $\mathrm{Gu}$ et al. (2011) with minor modifications. The pretreated placenta and enzyme mixture was centrifuged at $10,000 \times g$ for $5 \mathrm{~min}$. Gel permeation chromatography (GPC) was performed on the supernatant using a YL 9100 high performance liquid chromatography system (Younglin Instrument Co. Ltd., Korea) equipped with three Ultrahydrogel ${ }^{\mathrm{TM}} 120$ columns $(7.8 \times$ $3,000 \mathrm{~mm}$, Waters, USA). The mobile phase was distilled/ deionized water at a flow rate of $1 \mathrm{~mL} / \mathrm{min}$, and the $\mathrm{Mw}$ distributions of the collagen peptides were monitored using a YL 9100 refractive index detector (YL Instrument Co. Ltd., Korea) at $40^{\circ} \mathrm{C}$. A Mw standards kit (10620,100 Da, Polymer Standards Service, Mainz, Germany) was used as the standards.

\section{Statistical analysis}

A completely randomized design was adopted to evaluate the effect of enzyme concentration, incubation time as well as subcritical water processing using a SAS statistical program (SAS Institute, USA). Each determination was performed in triplicate, and the entire experiment was repeated three times. Representative data are presented. A $p<0.05$ was considered significant.

\section{Results and Discussion}

\section{Trypsin-catalyzed placental hydrolysis}

As depicted in Fig. 2A, trypsin displayed good hydro- lyzing activity for porcine placenta. The porcine placenta was composed of four peptides near 200 and $100 \mathrm{kDa}$. The former indicates $\alpha$-chains which have $M_{\mathrm{w}}$ of $116 \mathrm{kDa}$ and the latter were $\beta$-chains $(205 \mathrm{kDa})$ as revealed in other studies (Ahmad et al., 2010; Klomklao et al., 2006; Liu et al., 2012). The collagen peptides completely disappeared when the sample was reacted with trypsin for $1 \mathrm{~h}$, indicating that the placenta acted as a good substrate for trypsin. The catalytic action of trypsin hydrolyze the placenta was verified when enzyme concentration was reduced. No peptide bands were detected even if the enzyme concentration was decreased from 25.0 to $6.25 \mathrm{BAEE}$ unit/mg. It is well recognized that trypsin has optimum activity at $\mathrm{pH}$ 7-9 (Sipos and Merkel, 1970). The placental suspension $(\sim \mathrm{pH} 6.3)$ provided an optimum environment for trypsin activity, resulting in good tryptic placental digestion.

The peptide profiles of the placental hydrolysates revealed that trypsin produced mainly two groups of pep-

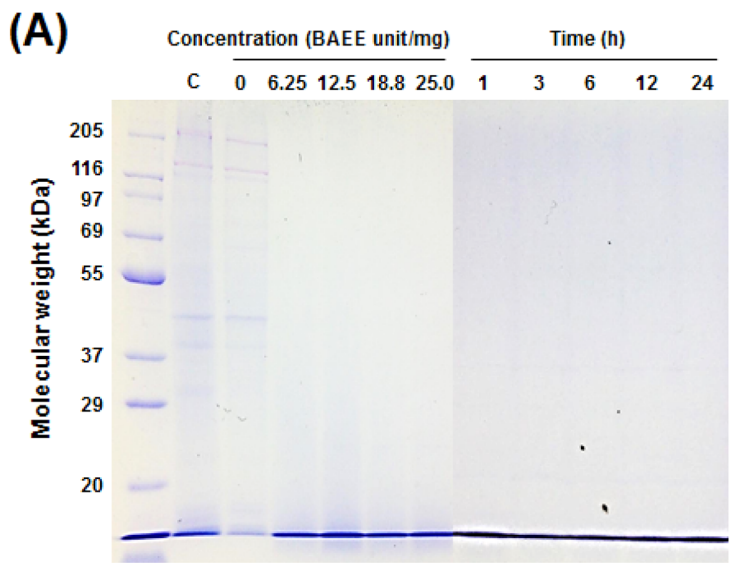

(B)

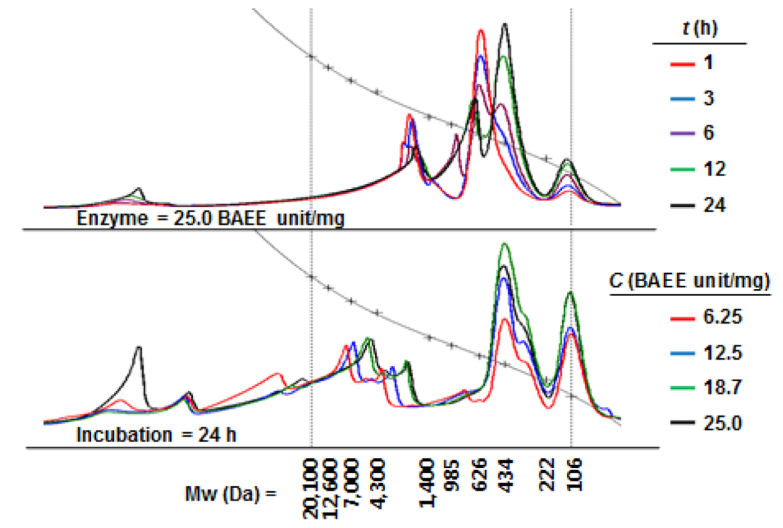

Fig. 2. Effects of trypsin concentration and incubation time on (A) sodium dodecyl sulfate-polyacrylamide gel electrophoresis pattern and (B) molecular weight distribution of preheated $\left(90^{\circ} \mathrm{C}\right.$ for $\left.1 \mathrm{~h}\right)$ porcine placenta hydrolysates. The placenta and enzyme mixture was incubated at $37^{\circ} \mathrm{C}$. 
tides, one group with a relatively high $\mathrm{Mw}(>20 \mathrm{kDa})$ and the other with a Mw of about 626 and $106 \mathrm{Da}$ after a $1 \mathrm{~h}$ incubation (Fig. 2B). Tryptic hydrolysis continued with increasing incubation time and the high $\mathrm{Mw}$ peptide peaks shifted toward the lower Mw range and the number of low Mw peptides increased. After $12 \mathrm{~h}$ incubation, the predominant peptide peaks obtained were $<1 \mathrm{kDa}$. In particular, the main peptide peaks were identified at 106 and $500 \mathrm{Da}$. Based on the $\mathrm{Mw}$ calculation, these peptides seemed to be composed of 1-5 amino acids. These results were identical when enzyme concentration was reduced. The lower the enzyme concentration, the higher the Mw distribution in the high $\mathrm{Mw}$ peptide group. However, the main $\mathrm{Mw}$ peaks were obtained at 106 and $500 \mathrm{kDa}$ regardless of enzyme concentration.

Consequently, trypsin showed good activity, producing low $\mathrm{Mw}$ collagen peptides $(<1 \mathrm{kDa})$ for use in functional foods. This activity resulted from specific cleavage site in substrates. Although, trypsin cleaves the C-terminal to arginine and lysine residues (Olsen et al., 2004), Rodriguez et al. (2008) postulated that it tends to cleave before proline. Proline is the most abundant amino acid in porcine placenta followed by glycine (Lee et al., 2013) which increased susceptibility to tryptic digestion.

\section{Pepsin-catalyzed placental hydrolysis}

The peptide bands in the placenta were not affected by pepsin treatment until $6 \mathrm{~h}$ of incubation, and hydrolysis occurred after $12 \mathrm{~h}$ (Fig. 3A). The peptide bands detected at $<36.5 \mathrm{kDa}$ disappeared if incubation time was extended to $24 \mathrm{~h}$. Maximum activity of pepsin occurs at about $\mathrm{pH} 2$, and pepsin is inactivated in neutral or alkaline conditions (Johnston et al., 2007). Based on the $\mathrm{pH}$ of the placental suspension ( $\sim \mathrm{pH} 6.3)$, pepsin seemed to be inadequate to hydrolyze the porcine placenta. According to the SDS-PAGE pattern, two peptide bands ( 20 and $37 \mathrm{kDa}$ ) were detected after $24 \mathrm{~h}$ incubation. The GPC pattern also indicated that low $\mathrm{Mw}$ peptide peaks $(<20 \mathrm{kDa})$ were not observed after a $6 \mathrm{~h}$ incubation (Fig. 3B). A new Mw peak was detected near $10 \mathrm{kDa}$ after $12 \mathrm{~h}$ of incubation and the major peaks were present at $>20 \mathrm{kDa}$. Low Mw peak hydrolysates were observed at $7 \mathrm{kDa}$ and $<626 \mathrm{Da}$ after $24 \mathrm{~h}$ incubation, however, the main portion of the peptides still existed at $>20 \mathrm{kDa}$.

Because of the poor collagen hydrolyzing activity of pepsin, decreasing the enzyme concentration resulted in relatively high $\mathrm{Mw}$ peptides according to both SDS-PAGE and GPC. Therefore, pepsin must be excluded as a collagen-hydrolyzing enzyme at near neutral conditions. The

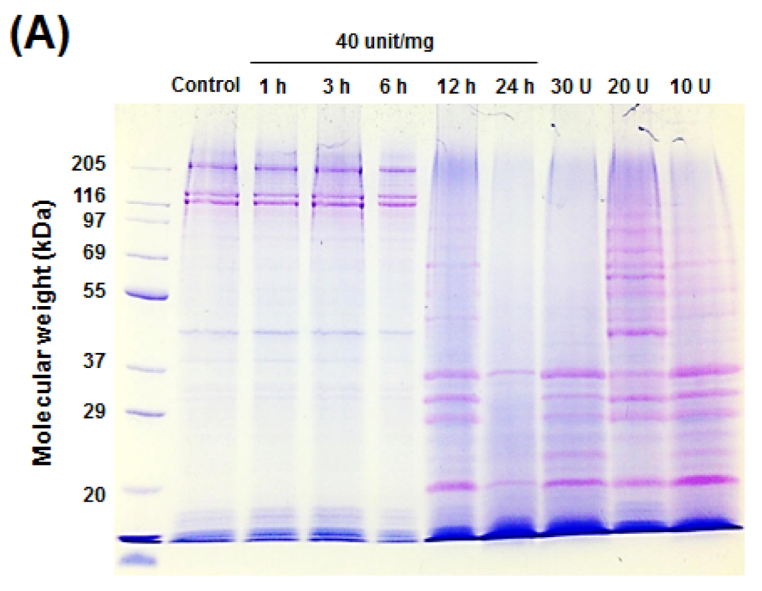

(B)

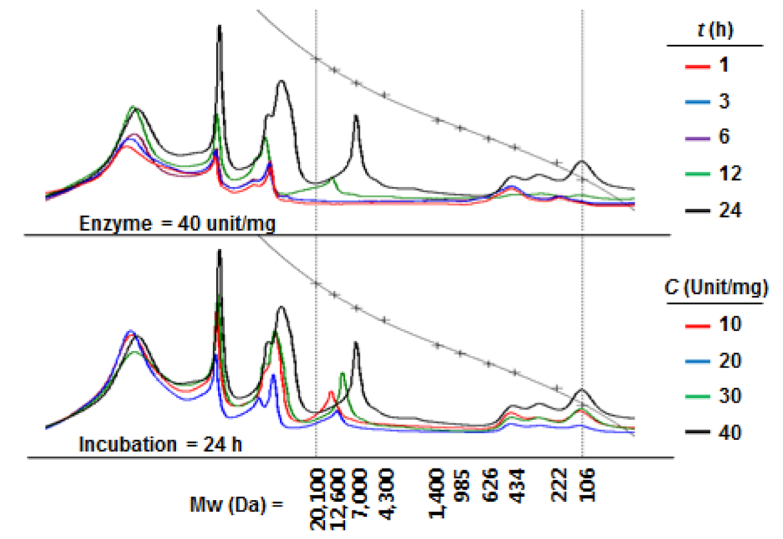

Fig. 3. Effects of pepsin concentration and incubation time on (A) sodium dodecyl sulfate-polyacrylamide gel electrophoresis pattern and (B) molecular weight distribution of preheated $\left(90^{\circ} \mathrm{C}\right.$ for $\left.1 \mathrm{~h}\right)$ porcine placenta hydrolysates. The placenta and enzyme mixture was incubated at $37^{\circ} \mathrm{C}$.

poor activity of pepsin could be explained by its protein cleaving sites, i.e., pepsin specifically cleaves the peptide bonds between hydrophobic and aromatic residues (Fruton, 1970; Kageyama, 2004), and showed limited and slow peptic digestion of the placenta. Consequently, the results indicate that pepsin cannot efficiently cleave porcine collagen because of the limited number of aromatic amino acids and inappropriate $\mathrm{pH}$ (Johnston et al., 2007; Lee et al., 2013).

\section{Chymotrypsin-catalyzed placental hydrolysis}

Chymotrypsin had potential application as a placental hydrolysis enzyme (Fig. 4A). Chymotrypsin-catalyzed collagen hydrolysis occurred after $1 \mathrm{~h}$ incubation, and the collagen chains revealed a different susceptibility to this enzyme. According to the SDS-PAGE pattern, the $\alpha$-chains of placental collagen $(\sim 116 \mathrm{kDa})$ digested gradually and 


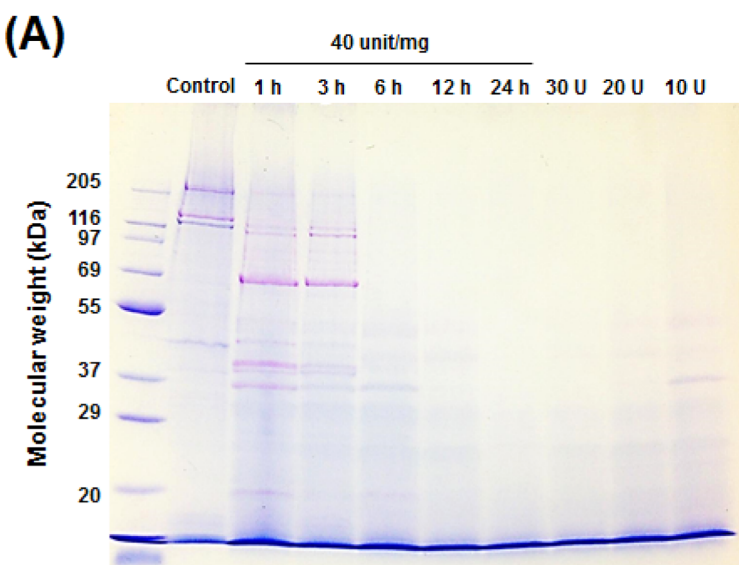

(B)

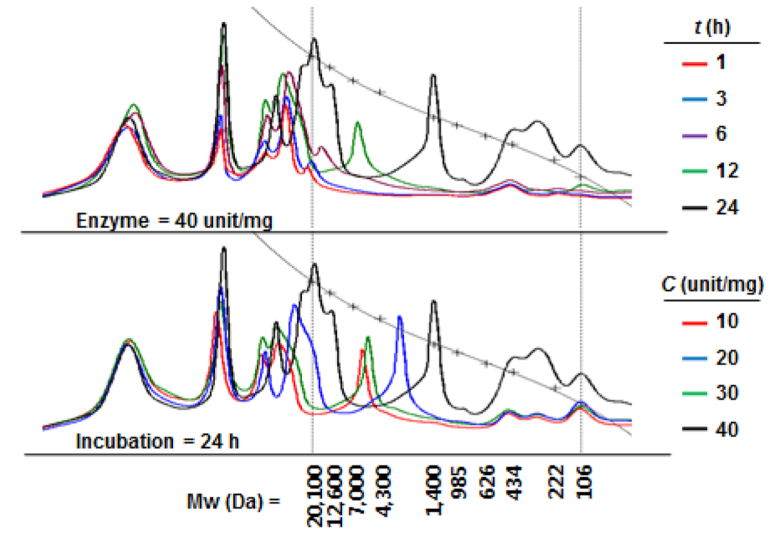

Fig. 4. Effects of chymotrypsin concentration and incubation time on (A) sodium dodecyl sulfate-polyacrylamide gel electrophoresis pattern and (B) molecular weight distribution of preheated $\left(90^{\circ} \mathrm{C}\right.$ for $\left.1 \mathrm{~h}\right)$ porcine placenta hydrolysates. The placenta and enzyme mixture was incubated at $37^{\circ} \mathrm{C}$.

completely disappeared after $6 \mathrm{~h}$ incubation. Meanwhile, $\beta$-chain ( $\sim 205 \mathrm{kDa})$ digestion was initiated faster than that of the $\alpha$-chains, and $\beta$-chain band intensity was smeared when new peptide bands appeared at $<69 \mathrm{kDa}$ after $1 \mathrm{~h}$ incubation. The hydrolysate bands disappeared completely after the $6 \mathrm{~h}$ incubation with the exception of a $37 \mathrm{kDa}$ peptide that lost its intensity after $12 \mathrm{~h}$ incubation. No visual difference in the SDS-PAGE pattern between 30 and 40 units/mg concentrations was observed. However, decreasing the enzyme concentration to $20 \mathrm{unit} / \mathrm{mg}$ resulted in minor bands at $20-30 \mathrm{kDa}$, and the bands were intense at an enzyme concentration of 10 units $/ \mathrm{mg}$.

The peptides hydrolyzed by chymotrypsin had relatively high Mw (>20 kDa) until $6 \mathrm{~h}$ of incubation (Fig. 4B). After $12 \mathrm{~h}$ incubation, a new peak was generated at $7 \mathrm{kDa}$, though the major Mw peaks were still detected at $>20$ $\mathrm{kDa}$. Increases in the low Mw peaks $(1.4 \mathrm{kDa}$ and $<434$

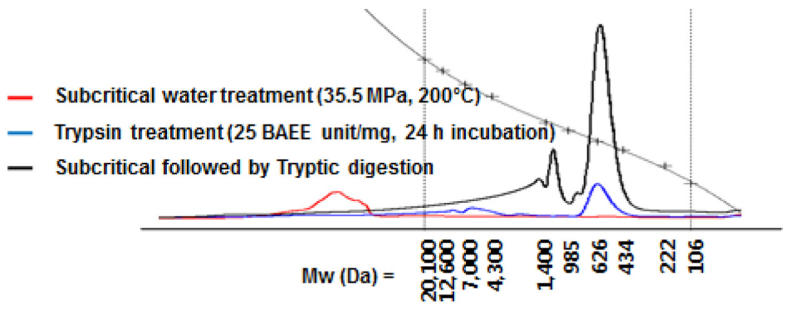

Fig. 5. Gel permeation chromatography pattern of preheated $\left(90^{\circ} \mathrm{C}\right.$ for $\left.1 \mathrm{~h}\right)$ and subcritical water processed $(37.5 \mathrm{MPa}$ and $200^{\circ} \mathrm{C}$ ) porcine placenta hydrolysates incubated with 25.0 BAEE unit/mg trypsin at $37^{\circ} \mathrm{C}$ for $24 \mathrm{~h}$.

Da) were obtained, but the half peak dimension belonged to the $20 \mathrm{kDa}$ peptides. The lower the enzyme concentration, the higher the Mw distribution of placental hydrolysates.

Although chymotrypsin exhibited less impact on collagen hydrolysis compared to trypsin, it was difficult to directly compare the hydrolyzing activity between the two enzymes due to differences in enzyme concentrations. Chymotrypsin preferentially cleaves peptide bonds connected with tyrosine, tryptophan, and phenylalanine (Appel, 1986; Ma et al., 2005; Vajda and Szabo, 1976). It is likely that the different substrate specificity of this enzyme caused different trypsin hydrolyzing activities, and an increase in enzyme concentration was required to observe the effect of chymotrypsin on placental hydrolysis. However, it should be noted that the commercial chymotrypsin product had a maximum activity of 40 units/mg. Consequently, it was expected that chymotryptic digestion would be successful by increasing the enzyme concentration, which warrants further exploration.

\section{Substrate processing}

As discussed earlier, insoluble collagen is not hydrolyzed by proteases; thus, all of the placenta were initially preheated to convert insoluble collagen to soluble gelatin. This preheating treatment was eventually replaced with subcritical water processing, and the samples were treated with trypsin (Fig. 5). The results revealed that subcritical water processing alone was unable to produce low $\mathrm{Mw}$ peptides, and the major peak was observed at about 10 $\mathrm{kDa}$, reflecting a limited collagen hydrolyzing effect of subcritical processing (Lee et al., 2013). Tryptic digestion of the subcritical water processed placenta produced a major peak at $626 \mathrm{Da}$ with a minor peak at about $1 \mathrm{kDa}$. Although no peak was observed at $106 \mathrm{Da}$ (free amino acids), subcritical processing seemed to be a better placental pre-treatment than preheating to produce low $\mathrm{Mw}$ 
placental hydrolysates.

\section{Concluding Remarks}

The present study demonstrated the effects of proteases on hydrolysis activity of porcine placenta. The insoluble collagen had to be converted to soluble gelatin for the enzymes to act. This conversion procedure is traditionally conducted by thermal treatment, however, subcritical water processing allowed the protease to hydrolyze the placenta effectively. Because of differences in substrate specificity and optimum conditions, trypsin was the best enzyme to hydrolyze placenta. However, pepsin and chymotrypsin might be applicable if experimental conditions are optimized for these enzymes, which warrant further exploration.

\section{Acknowledgements}

Financial support for this study was obtained from the Korean Institute of Planning and Evaluation for Technology in Food, Agriculture, Forest, and Fisheries, Korea (iPET Project No. 311029-3).

\section{References}

1. Ahmad, M., Benjakul, S., and Nalinanon, S. (2010) Compositional and physicochemical characteristics of acid solubilized collagen extracted from the skin of unicorn leatherjacket (Aluterus monoceros). Food Hydrocolloid. 24, 588-594.

2. AOAC (1990) Official methods of analysis. 15th ed, Association of Official Analytical Chemists, Washington, DC.

3. Appel, W. (1986) Chymotrypsin: molecular and catalytic properties. Clin. Biochem. 19, 317-322.

4. Brunner, G. (2009) Near critical and supercritical water. Part I. Hydrolytic and hydrothermal processes. J. Supercritical Fluid. 47, 373-381.

5. Chai, H. J., Li, J. H., Huang, H. N., Li, T. L., Chan, Y. L., Shiau, C. Y., and Wu, C. J. (2010) Effects of sizes and conformations of fish-scale collagen peptides on facial skin qualities and transdermal penetration efficiency. J. Biomed. Biotechnol. 2010, 1-9.

6. Denis, A., Brambati, N., Dessauvages, B., Guedj, S., Ridoux, C., Meffre, N., and Autier, C. (2008) Molecular weight determination of hydrolyzed collagens. Food Hydrocolloid. 22, 989-994.

7. Fruton, J. S. (1970) The specificity and mechanism of pepsin action. Adv. Enzymol. Relat. Areas Mol. Bio. 33, 401-443.

8. Gómez-Guillén, M. C., Giménez, B., López-Caballero, M. E., and Montero, M. P. (2011) Functional and bioactive properties of collagen and gelatin from alternative sources: A review. Food Hydrocolloid. 25, 1813-1827.

9. Gu, R. Z., Li, C. Y., Liu, W. Y., Yi, W. X. and Cai, M. Y. (2011) Angiotensin I-converting enzyme inhibitory activity of low-molecular-weight peptides from Atlantic salmon (Salmo salar L.) skin. Food Res. Int. 44, 1536-1540.

10. He, S., Franco, C., and Zhang, W. (2013) Functions, applications and production of protein hydrolysates from fish processing co-products (FPCP). Food Res. Int. 50, 289-297.

11. Johnston, N., Dettmar, P. W., Bishwokarma, B., Lively, M. O., and Koufman, J. A. (2007) Activity/stability of human pepsin: Implications for reflux attributed laryngeal disease. Laryngoscope 117, 1036-1039.

12. Kageyama, T. (2004) Role of S'1 loop residues in the substrate specificities of pepsin A and chymosin. Biochem. 43, 15122-15130.

13. Klomklao, S., Benjakul, S., Visessanguan, W., Kishimura, H., and Simpson, B. K. (2006) Proteolytic degradation of sardine (Sardinella gibbosa) proteins by trypsin from skipjack tuna (Katsuwonus pelamis) spleen. Food Chem. 98, 1422.

14. Laemmli, U. K. (1970) Cleavage of structural proteins during assembly of head of bacteriophage T4. Nature 227, 680685.

15. Lee, M. Y., Choi, Y. C., Chun, J. Y., Min, S. G., and Hong, G. P. (2013) Effects of high pressure/high temperature processing on the recovery and characteristics of porcine placenta hydrolysates. Korean J. Food Sci. An. 33, 474-480.

16. Liu, D., Liang, L., Regenstein, J. M. and Zhou, P. (2012) Extraction and characterization of pepsin-solubilised collagen from fins, scales, skins, bones and swim bladders of bighead carp (Hypophthalmichthys nobilis). Food Chem. 133, 1441-1448.

17. Ma, W., Tang, C., and Lai, L. (2005) Specificity of trypsin and chymotrypsin: Loop-motion-controlled dynamic correlation as a determinant. Biophys. J. 89, 1183-1193.

18. Miller, E. J. (1988) Collagen types: Structure, distribution, and functions. In: Collagen. Nimni, M. E. (ed) Boca Raton, CRC Press, Boca Raton, vol. 1, pp. 139-156.

19. Olsen, J. V., Ong, S., and Mann, M. (2004) Trypsin cleaves exclusively $\mathrm{C}$-terminal to arginine and lysine residues. Mol. Cell Proteomics 3, 608-614.

20. Rodriguez, J., Gupta, N., Smith, R. D., and Prevner, P. A. (2008) Does trypsin cut before proline? J. Proteome Res. 7, 300-305.

21. Sipos, T. and Merkel, J. R. (1970) An effect of calcium ions on the activity, heat stability, and structure of trypsin. Biochem. 9, 2766-2775.

22. Vajda, T. and Szabo, T. (1976) Specificity of trypsin and alpha-chymotrypsin towards neutral substrates. Acta Biochim. Biophys. Acad. Sic. Hung. 11, 287-294.

23. Watchararuji, K., Goto, M., Sasaki, M., and Shotiprunk, A. (2008) Value-added subcritical water hydrolysate from rice bran and soybean meal. Bioresour. Technol. 99, 6207-6213.

24. Yang, Y., Hawthorne, S. B., and Miller, D. J. (1997) Classselective extraction of polar, moderately polar, and nonpolar organics from hydrocarbon wastes using subcritical water. 
Environ. Sci. Technol. 31, 430-437.

25. Yorgancioglu, A. and Bayramoglu, E. E. (2013) Production of cosmetic purpose collagen containing antimicrobial emulsion with certain essential oils. Ind. Crop. Prod. 44, 378-382.

26. Zhang, Z., Li, G., and Shi, B. (2006) Physicochemical prop- erties of collagen, gelatin and collagen hydrolysate derived from bovine limed split wastes. J. Society Leather Technol. Chem. 90, 23-28.

$\overline{\text { (Received 2013.8.17/Revised 2014.1.2/Accepted 2014.2.10) }}$ 